\title{
Efek suplementasi vitamin A pada ibu nifas terhadap pertumbuhan bayi umur $0-4$ bulan
}

\author{
Effect of vitamin A supplementation for mothers at parturition period to growth of infants of 0-4 months
}

Abdullah $^{1}$, Endy Paryanto Prawirohartono ${ }^{2}$, Siti Helmyati ${ }^{3}$

\begin{abstract}
Background: Vitamin A deficiency is a nutritional problem in infants since breastmilk insufficiently contains vitamin A. Therefore it is necessary to study the effect of vitamin A supplementation to mothers at parturition period on growth and morbidities of infants at 0-4 months of age.

Objective: To identify the effect of vitamin A supplementation to mothers at parturition period on growth and morbidities of infants at 0-4 months of age.

Method: We conducted a randomized controlled trial from March-July 2009 at Province of Lampung. We recruited 90 mothers that were grouped into vitamin A supplementation group and socialization about vitamin $A$ group during parturition period. The outcomes of this study were growth in WHZ and morbidities of infants at 0-4 months of age measured as duration of acute diarrhea and upper respiratory infections. Statistical analysis was performed by using Chi-Square and t-test.

Results: The growth of infants of 0-4 months from vitamin A supplemented mothers was not significantly different from the socialization group. Duration of diarrhea and acute respiratory tract infection of infants from supplemented mothers at parturition period was significantly shorter than of infants from socialization group.

Conclusion: The growth of infant at 0-4 months of age from vitamin A supplemented mothers at parturition period were not significantly different from those who were from education group. Duration of diarrhea and acute respiratory tract infection of infants from vitamin A supplemented mothers at parturition period were shorter than those who were from education group.
\end{abstract}

KEY WORDS: vitamin A supplementation, mothers at parturition period, infant, growth, morbidities

\begin{abstract}
ABSTRAK
Latar belakang: Salah satu penyebab kurang gizi pada bayi adalah kekurangan vitamin A karena ASI tidak cukup mengandung vitamin A. Perlu dilakukan penelitian untuk mengevaluasi pengaruh pemberian suplementasi dan penyuluhan vitamin A pada ibu nifas terhadap pertumbuhan dan morbiditas bayi umur 0-4 bulan.

Tujuan: Mengetahui pengaruh pemberian suplementasi vitamin A dan penyuluhan vitamin A pada ibu nifas terhadap pertumbuhan dan morbiditas bayi umur 0-4 bulan.

Metode: Penelitian dengan rancangan randomized controlled trial ini dilaksanakan pada bulan Maret-Juli 2009 di Provinsi Lampung dengan mengikutsertakan 90 ibu yang dibedakan dalam 2 kelompok yaitu kelompok suplementasi vitamin A dan kelompok penyuluhan vitamin A. Pertumbuhan bayi dinyatakan dengan perubahan berat badan menurut panjang badan (BB/PB) atau weight for length and weight for height z-score (WHZ) bayi umur 0 - 4 bulan dan diukur setiap bulan sekali selama 4 bulan sedangkan morbiditas diukur berdasarkan durasi diare dan infeksi pernapasan akut. Analisis statistik dilakukan dengan menggunakan uji Chi-Square dan t-test.

Hasil: Pertumbuhan WHZ bayi dari umur 0-4 bulan pada kelompok bayi dari ibu nifas yang mendapat suplementasi vitamin A tidak berbeda bermakna dibandingkan dengan kelompok bayi dari ibu yang mendapat penyuluhan vitamin $A(p>0,05)$. Durasi diare dan ISPA kelompok bayi dari ibu nifas yang mendapat suplementasi vitamin $A$ lebih rendah secara bermakna dibandingkan dengan bayi dari ibu nifas yang mendapat penyuluhan vitamin $A(p<0,05)$.

Simpulan: Suplementasi vitamin A pada ibu nifas tidak mempengaruhi pertumbuhan bayi umur 0-4 bulan tetapi menurunkan durasi diare dan infeksi saluran pernapasan.
\end{abstract}

KATA KUNCI: suplementasi vitamin A, ibu nifas, pertumbuhan, morbiditas

\section{PENDAHULUAN}

Setiap anak yang dilahirkan pada dasarnya memiliki garis pertumbuhan normal (growth trajectory) masingmasing (1), tetapi dalam kehidupan selanjutnya telah terjadi penyimpangan pertumbuhan yang tidak sesuai dengan garis pertumbuhan normal yang disebut dengan gangguan pertumbuhan (growth faltering) (2). Gangguan
1 Korespondensi: Dinas Kesehatan Provinsi Lampung, Jl. Dr. Susilo No. 44 Pahoman, Bandar Lampung, Telp. (0721) 252412, e-mail: changdullah66@yahoo.com

2 Ilmu Kesehatan Anak, Rumah Sakit Umum Pusat Dr. Sardjito/ Fakultas Kedokteran Universitas Gadjah Mada, Jl. Kesehatan No 1, Yogyakarta 55281, e-mail: prawirohartonoendypyt@yahoo.co.id

3 Program Studi Gizi Kesehatan, Fakultas Kedokteran Universitas Gadjah Mada, Jl. Farmako, Sekip Utara, Yogyakarta 55281 
pertumbuhan dipengaruhi oleh status gizi dan kesehatan ibu, asupan gizi yang kurang, berat badan lahir rendah, "care" atau perawatan ibu, kekurangan gizi pada masa janin, tidak memberikan air susu ibu (ASI) secara eksklusif, dan pemberian makanan pendamping ASI (MP-ASI) pada usia terlalu dini (3). Faktor lain yang mempengaruhi gangguan pertumbuhan yaitu penyakit infeksi terutama diare dan infeksi saluran pernapasan akut (ISPA) (4-6).

Zat-zat gizi yang secara spesifik berhubungan dengan gangguan pertumbuhan adalah energi, protein, seng, tembaga, yodium, dan vitamin A (7). Vitamin A tidak hanya berfungsi dalam penglihatan tetapi juga mempunyai peranan untuk pertumbuhan sebagaimana telah diperkenalkan melalui penelitian di Aceh, Indonesia sejak tahun 1913 (8) yang menyatakan bahwa pemberian suplementasi vitamin A sebagai alternatif untuk memperbaiki pertumbuhan anak. Penelitian pada anak sekolah yang dilakukan di Indonesia pada tahun 2000 menunjukkan bahwa pemberian suplementasi vitamin A dosis tinggi dapat meningkatkan pertumbuhan linier pada anak yang memiliki kadar retinol serum sangat rendah dan efek ini dipengaruhi oleh usia dan ASI (9).

Bayi yang baru dilahirkan mempunyai cadangan vitamin A yang terbatas dalam tubuhnya dan hanya mencukupi kebutuhan untuk dua minggu saja. Oleh karena itu, pemenuhan vitamin A idealnya hanya diperoleh dari ASI (10). Penelitian pemberian vitamin A pada ibu nifas telah banyak dilakukan meskipun dengan hasil yang berbedabeda. Penelitian yang pernah dilakukan pada anak usia 6 bulan dengan ibu yang memperoleh vitamin A pada saat nifas menunjukkan penurunan jumlah kasus demam dan waktu kesembuhan lebih cepat ketika terkena ISPA (10).

Berdasarkan permasalahan tersebut, penelitian ini dilakukan untuk mengetahui perbedaan pertumbuhan bayi umur 0-4 bulan dari ibu yang mendapat suplementasi vitamin A dibandingkan dengan ibu yang mendapat penyuluhan vitamin A pada masa nifas.

\section{BAHAN DAN METODE}

Penelitian ini merupakan penelitian eksperimental dengan rancangan randomized controlled trial. Jenis perlakuan dalam penelitian ini dibedakan menjadi dua yaitu kelompok perlakuan pertama diberikan suplementasi vitamin A 200.000 IU sebanyak dua kapsul dan kelompok perlakuan kedua diberikan penyuluhan tentang vitamin A sebanyak satu kali melalui media leaflet tanpa suplementasi vitamin $A$ $200.000 \mathrm{IU}$. Outcome yang diamati adalah pertumbuhan bayi sejak lahir sampai berumur 4 bulan. Suplementasi vitamin A yang digunakan adalah vitamin A dosis tinggi $200.000 \mathrm{IU}$ dari program Departemen Kesehatan Republik Indonesia. Perlakuan terhadap kedua kelompok dilakukan sekali selama masa nifas dan observasi pertumbuhan kepada bayi dilakukan setiap bulan sekali selama 4 bulan.
Penelitian dilakukan di Kecamatan Gedong Tataan, Kabupaten Pesawaran, Provinsi Lampung dengan pertimbangan bahwa Kecamatan Gedong Tataan merupakan ibukota Kabupaten Pesawaran dengan luas wilayah 9.706 ha dan merupakan wilayah kecamatan yang luasnya terkecil dibandingkan dengan 6 kecamatan lainnya di Kabupaten Pesawaran. Selain itu, Kecamatan Gedong Tataan memiliki dua puskesmas yaitu Puskesmas Bernung dengan wilayah kerja 8 desa dan Puskesmas Gedong Tataan dengan wilayah kerja 11 desa yang dibatasi oleh perkebunan. Puskesmas Gedong Tataan terletak di bagian barat sedangkan Puskesmas Bernung terletak di bagian utara yang dipisahkan oleh areal perkebunan dengan jarak sekitar 500 meter yang bertujuan menghindari terjadinya kontaminasi antara dua kelompok perlakuan. Penetapan lokasi dilakukan secara random lokasi dengan cara undian. Seluruh desa dijadikan sebagai lokasi penelitian dengan jumlah lokasi yang tecatat pada kelompok suplementasi adalah 8 desa dan kelompok penyuluhan adalah 11 desa.

Ibu nifas sebagai subjek diperoleh dengan cara melakukan kunjungan kepada para bidan yang telah melakukan pertolongan persalinan pada bulan Maret 2009, daftar nama ibu nifas dicatat secara lengkap dan kemudian dilanjutkan kunjungan ke ibu nifas. Waktu penelitian dilaksanakan pada bulan Maret sampai dengan Juli 2009. Subjek penelitian adalah ibu nifas dengan bayi umur 0-4 bulan yang dilahirkan dengan pertolongan bidan pada bulan yang sama dan dalam jangka waktu satu bulan sejak tanggal 1 sampai dengan 31 Maret 2009. Kriteria inklusi yaitu ibu dalam masa nifas, bayi yang dilahirkan dengan berat badan paling rendah 2.500 gram, dan bersedia menjadi subjek penelitian dengan menandatangani surat persetujuan tertulis (written informed consent untuk ibu dan proxy consent untuk bayinya). Kriteria eksklusi adalah bayi yang menderita kelainan atau cacat bawaan yang dapat mengganggu proses pertumbuhan seperti sindrom Down dan ibu menderita penyakit kronis berdasarkan diagnosis dokter puskesmas.

Subjek penelitian yang sudah memenuhi kriteria dipilih secara random. Randomisasi dilakukan pada saat subjek mempunyai bayi yang sudah mencapai umur satu bulan dengan cara undian pada masing-masing kelompok sebanyak 45 orang. Besar sampel dihitung berdasarkan rumus besar sampel beda rata-rata dua populasi (11) dengan rerata kedua variasi standar deviasi (BB/U) sebesar 0,274 (12), tingkat kepercayaan $95 \%$, power $90 \%$, perbedaan rerata berat badan antara kelompok perlakuan dengan kelompok kontrol ( $\mu 1-\mu 2)$ sebesar 0,36 (12) sehingga jumlah sampel minimal sebanyak 45 orang.

Empat jenis variabel yang diteliti dalam penelitian ini yaitu variabel bebas (perlakuan suplementasi dan penyuluhan), variabel terikat (pertumbuhan bayi), variabel antara (karakteristik keluarga, frekuensi ASI, 
Tabel 1. Karakteristik keluarga subjek penelitian

\begin{tabular}{|c|c|c|c|c|c|}
\hline \multirow[t]{2}{*}{ Karakteristik } & \multicolumn{2}{|c|}{$\begin{array}{l}\text { Suplementasi } \\
\quad(n=45)\end{array}$} & \multicolumn{2}{|c|}{$\begin{array}{c}\text { Penyuluhan } \\
(n=45)\end{array}$} & \multirow[t]{2}{*}{$\mathbf{p}$} \\
\hline & $\mathbf{n}$ & $\%$ & $\mathbf{n}$ & $\%$ & \\
\hline \multicolumn{6}{|l|}{ Orang tua } \\
\hline Pendidikan ayah rendah@ & 29 & 64,4 & 20 & 44,4 & 0,057 \\
\hline Pendidikan ibu rendah@ & 24 & 53,3 & 24 & 53,3 & 1,000 \\
\hline Pekerjaan ayah pegawai/usaha & 25 & 55,6 & 19 & 42,2 & 0,206 \\
\hline Pekerjaan ibu rumah tangga & 33 & 73,3 & 34 & 75,6 & 0,809 \\
\hline Penghasilan rendah\# & 27 & 60,6 & 32 & 71,1 & 0,267 \\
\hline \multicolumn{6}{|l|}{ Anak } \\
\hline Jenis kelamin perempuan & 26 & 57,8 & 19 & 42,2 & 0,206 \\
\hline Imunisasi tidak lengkap $\$$ & 12 & 26,7 & 18 & 40,0 & 0,264 \\
\hline Umur kehamilan $<37$ minggu & 5 & 11,1 & 3 & 6,7 & 0,714 \\
\hline Nomor urut anak $>1$ & 23 & 51,1 & 18 & 40,0 & 0,290 \\
\hline \multicolumn{6}{|l|}{ Fasilitas keluarga } \\
\hline Lantai tanah & 2 & 4,4 & 4 & 8,9 & 0,398 \\
\hline Sumber air minum bersih $§$ & 18 & 40,0 & 5 & 11,1 & $0,002^{*}$ \\
\hline Jamban higienis" & 39 & 86,7 & 32 & 71,1 & 0,070 \\
\hline
\end{tabular}

Keterangan :

@ pendidikan SMP, SD, tidak sekolah

\# penghasilan < Rp 1.000.000,-

$\$$ tidak mendapat salah satu atau semua imunisasi BCG, DPT (1-3), Hepatitis B (1-3)

$\S$ PAM, ledeng umum, sumur bor, sumur gali terlindung, mata air terlindung, dan koleksi air hujan

ๆ WC umum, sistem septik, jamban sederhana, dan jamban berventilasi baik

* bermakna $(p<0,05)$

dan asupan zat gizi), dan variabel luar (frekuensi serta durasi ISPA dan diare). Pengukuran pertumbuhan bayi menurut weight for length/height z-score (WHZ) diperoleh melalui penimbangan berat badan (BB) dan pengukuran panjang badan (PB) setiap bulan sekali selama 4 bulan. Pengukuran BB menggunakan timbangan bayi (baby scale) dengan ketelitian 0,01 kg sedangkan pengukuran PB menggunakan length board dengan ketelitian 0,1 $\mathrm{cm}$. Data hasil pencatatan pengukuran antropometri diinput dengan menggunakan software WHO Anthro 2005 sehingga diperoleh hasil pengukuran adalah rerata $\mathrm{WHZ}$.

Karakteristik keluarga diperoleh dengan wawancara menggunakan formulir. Frekuensi ASI dan asupan zat gizi (energi, protein, vitamin A, besi, dan seng baik yang bersumber dari ASI, MP-ASI, atau susu formula) diukur dengan metode recall $1 \times 24$ jam setiap bulan sekali selama 4 bulan. Hasil pengukuran berupa rata-rata frekuensi menyusui dalam sehari dan rerata asupan zat gizi yang dikategorikan berdasarkan cut off point asupan baik jika memenuhi $80 \%$ dari angka kecukupan gizi (AKG). Data asupan MP-ASI dan susu formula hasil recall diinput menggunakan software nutrisurvey sedangkan asupan ASI menggunakan software nUTri2008.

Frekuensi ISPA adalah rerata jumlah berapa kali bayi terkena ISPA dalam episode selama penelitian. Durasi ISPA adalah rerata lamanya hari sakit ISPA yang dihitung secara total selama penelitian 120 hari (4 bulan). Frekuensi diare adalah rerata jumlah berapa kali bayi mengalami diare dalam episode selama penelitian yang dihitung selama minimal 48 jam sembuh. Durasi diare adalah rata-rata jumlah hari sakit diare yang diderita oleh bayi selama penelitian 120 hari (4 bulan) yang ditandai dengan buang air besar dengan konsistensi tinja lembek (loose) atau cair (watery) 5-6 kali atau lebih sehari.

Analisis statistik yang digunakan adalah Chi-Square test yaitu untuk menguji kemaknaan 2 variabel nominal sedangkan t-test digunakan untuk menguji kemaknaan perbedaan 2 mean. Penelitian ini sudah memperoleh surat keterangan kelaikan etik (ethical clearance) dari Komisi Etik Penelitian Kedokteran dan Kesehatan, Fakultas Kedokteran Universitas Gadjah Mada.

\section{HASIL}

\section{Karakteristik subjek penelitian}

Karakteristik umur orang tua antara kelompok yang mendapat suplementasi dengan kelompok yang mendapat penyuluhan tidak berbeda bermakna $(p=0,210$ untuk umur ayah dan $p=0,173$ untuk umur ibu), demikian juga untuk karakteristik yang lain kecuali sumber air bersih. Kelompok suplementasi lebih banyak yang menggunakan sumber air bersih dibandingkan dengan kelompok penyuluhan $(40,0 \%$ vs $11,1 \% ; p=0,002$ ) (Tabel 1).

\section{Pertumbuhan}

Pertumbuhan bayi menurut $\mathrm{WHZ}$ antara 0 dan 4 bulan tidak berbeda bermakna antara kelompok bayi dari ibu yang mendapat suplementasi vitamin $A$ dengan kelompok bayi dari ibu yang mendapat penyuluhan $(p>0,05)$. Pertumbuhan bayi menurut sosial ekonomi 
Tabel 2. Pertumbuhan WHZ bayi sejak lahir sampai dengan umur 4 bulan

\begin{tabular}{|c|c|c|c|c|}
\hline \multirow{2}{*}{ Variabel } & \multicolumn{3}{|c|}{ Pertumbuhan WHZ } & \multirow[b]{2}{*}{$\mathbf{p}$} \\
\hline & $\mathrm{n}$ & rerata & SD & \\
\hline \multicolumn{5}{|l|}{ Perlakuan } \\
\hline Suplementasi & 45 & 0,051 & 1,881 & 0,292 \\
\hline Penyuluhan & 45 & 0,486 & 2,015 & \\
\hline \multicolumn{5}{|l|}{ Pendidikan ayah } \\
\hline Rendah@ & 49 & 0,153 & 1,926 & 0,540 \\
\hline Tinggi & 41 & 0,407 & 1,993 & \\
\hline \multicolumn{5}{|l|}{ Pendidikan ibu } \\
\hline Rendah@ & 48 & 0,375 & 1,910 & 0,582 \\
\hline Tinggi & 42 & 0,147 & 2,001 & \\
\hline \multicolumn{5}{|l|}{ Pekerjaan ayah } \\
\hline Petani/buruh & 46 & 1,620 & 1,777 & 0,911 \\
\hline Pegawai/usaha & 44 & 1,690 & 2,136 & \\
\hline \multicolumn{5}{|l|}{ Pekerjaan ibu } \\
\hline Ibu rumah tangga & 67 & 0,180 & 1,963 & 0,466 \\
\hline Petani/buruh & 23 & 0,526 & 1,932 & \\
\hline \multicolumn{5}{|l|}{ Penghasilan } \\
\hline Rendah\# & 59 & 0,175 & 2,076 & 0,534 \\
\hline Tinggi & 31 & 0,446 & 1,703 & \\
\hline \multicolumn{5}{|l|}{ Frekuensi menyusui } \\
\hline$<8$ kali & 17 & $-0,821$ & 2,086 & $0,010^{*}$ \\
\hline$\geq 8$ kali & 73 & 0,522 & 1,841 & \\
\hline
\end{tabular}

Keterangan: @ pendidikan SMP, SD, tidak sekolah;

\# penghasilan < Rp 1.000.000,-;

* bermakna $(p<0,05)$;

$\mathrm{WHZ}=$ weight for length/height $\mathrm{z}$-score; $\mathrm{SD}=$ standar deviasi

keluarga menunjukkan bahwa faktor sosial ekonomi yaitu pendidikan, pekerjaan, dan penghasilan orang tua tidak berpengaruh terhadap pertumbuhan WHZ bayi sejak lahir sampai dengan umur 4 bulan ( $p>0,05)$ (Tabel 2).

Berdasarkan hasil penelitian ini ditemukan bahwa praktik pemberian ASI eksklusif sampai 4 bulan hanya sebesar $17,8 \%$ dan rerata frekuensi menyusui adalah 10,47 kali/hari. Rerata frekuensi menyusui pada kelompok bayi dari ibu yang mendapatkan suplementasi vitamin A adalah 10,98 kali/hari sedangkan pada kelompok penyuluhan adalah 9,96 kali/hari. Perubahan pertumbuhan WHZ bayi sejak lahir sampai dengan umur 4 bulan menurut frekuensi menyusui menunjukkan bahwa ada pengaruh frekuensi menyusui terhadap pertumbuhan $\mathrm{WHZ}(\mathrm{p}=0,01)$ (Tabel 2). Selisih nilai perubahan pertumbuhan $\mathrm{WHZ}$ antara kelompok bayi yang mendapatkan rerata frekuensi menyusui kurang dari 8 kali sehari dengan kelompok bayi yang mendapatkan rerata frekuensi menyusui sama dengan 8 kali sehari atau lebih sebesar 1,343 SD.

\section{Pertumbuhan menurut asupan zat gizi}

Asupan bayi umur 0-4 bulan selain dari ASI juga diperoleh dari MP-ASI dan susu formula. Pada penelitian ini ditemukan rerata total asupan zat gizi bayi hampir seluruhnya di atas $80 \%$ AKG kecuali asupan seng yang
Tabel 3. Pertumbuhan WHZ bayi sejak lahir sampai dengan umur 4 bulan menurut asupan zat gizi

\begin{tabular}{|c|c|c|c|c|}
\hline \multirow{2}{*}{ Asupan zat gizi } & \multicolumn{3}{|c|}{ Pertumbuhan WHZ } & \multirow[b]{2}{*}{ p } \\
\hline & $\mathbf{n}$ & rerata & SD & \\
\hline \multicolumn{5}{|l|}{ Energi (kcal) } \\
\hline$<80 \%$ AKG & 37 & 0,154 & 2,092 & 0,645 \\
\hline$\geq 80 \%$ AKG & 34 & 0,349 & 1,861 & \\
\hline \multicolumn{5}{|l|}{ Protein (g) } \\
\hline$<80 \%$ AKG & 34 & 0,359 & 2,119 & 0,733 \\
\hline$\geq 80 \%$ AKG & 56 & 0,214 & 1,858 & \\
\hline \multicolumn{5}{|l|}{ Vitamin A $(\mu \mathrm{g})$} \\
\hline$<80 \%$ AKG & 7 & 1,051 & 1,838 & 0,062 \\
\hline$\geq 80 \%$ AKG & 83 & 0,380 & 1,928 & \\
\hline \multicolumn{5}{|l|}{ Besi (mg) } \\
\hline$<80 \%$ AKG & 27 & 0,488 & 1,597 & 0,488 \\
\hline$\geq 80 \%$ AKG & 63 & 0,175 & 2,088 & \\
\hline \multicolumn{5}{|l|}{ Seng (mg) } \\
\hline$<80 \%$ AKG & 84 & 0,235 & 1,975 & 0,540 \\
\hline$\geq 80 \%$ AKG & 6 & 0,743 & 1,632 & \\
\hline
\end{tabular}

Tabel 4. Perbedaan frekuensi dan durasi sakit diare dan ISPA dari lahir sampai dengan umur 4 bulan

\begin{tabular}{|c|c|c|c|c|c|}
\hline \multirow{2}{*}{ Karakteristik } & \multicolumn{2}{|c|}{ Suplementasi } & \multicolumn{2}{|c|}{ Penyuluhan } & \multirow{2}{*}{$\mathbf{p}$} \\
\hline & rerata & SD & rerata & SD & \\
\hline \multicolumn{6}{|l|}{ Diare } \\
\hline Frekuensi (kali) & 1,07 & 0,252 & 1,22 & 0,420 & $0,036^{*}$ \\
\hline Durasi (hari) & 1,09 & 0,288 & 1,22 & 0,420 & 0,083 \\
\hline \multicolumn{6}{|l|}{ ISPA } \\
\hline Frekuensi (kali) & 1,42 & 0,499 & 1,67 & 0,499 & $0,020^{*}$ \\
\hline Durasi (hari) & 1,18 & 0,387 & 1,33 & 0,477 & 0,093 \\
\hline
\end{tabular}

Keterangan: * bermakna $(p<0,05) ; S D=$ standar deviasi

masih di bawah 80\% AKG. Rerata asupan energi adalah 560 kcal (86,42\% AKG); protein 12,66 g (95,2\% AKG); vitamin A $485 \mu \mathrm{g}$ (129\% AKG); besi 1,5 mg (300\% AKG); dan seng $0,53 \mathrm{mg}(40,8 \% \mathrm{AKG})$. Sumber energi bayi diperoleh dari ASI $(74,1 \%)$, susu formula $(8,9 \%)$, dan MPASI (3,5\%). Jenis MP-ASI yang sering diberikan adalah pisang, nasi, bubur, gula, dan air tajin. Pertumbuhan bayi menurut asupan zat gizi menunjukkan bahwa asupan zat gizi tidak mempengaruhi pertumbuhan $\mathrm{WHZ}$ bayi sejak lahir sampai dengan umur 4 bulan $(p>0,05)$ (Tabel 3$)$.

\section{Diare dan ISPA}

Rerata frekuensi sakit diare pada kelompok yang mendapat suplementasi lebih rendah dibandingkan kelompok yang mendapat penyuluhan dan hasil uji statistik menunjukkan ada perbedaan bermakna antara kedua kelompok ( 1,07 vs 1,22 kali; $p=0,036)$. Demikian pula dengan rerata frekuensi sakit ISPA pada kelompok yang mendapat suplementasi lebih rendah secara bermakna dibandingkan kelompok yang mendapat penyuluhan (1,42 vs 1,67 kali; $p=0,020)$ (Tabel 4). 


\section{BAHASAN}

Hasil penelitian ini menunjukkan bahwa pemberian suplementasi vitamin A pada ibu nifas tidak berpengaruh secara bermakna terhadap pertumbuhan bayi umur 0 - 4 bulan. Data ini konsisten dengan hasil penelitian di India pada tahun 2000 yang membuktikan bahwa suplementasi vitamin A pada ibu nifas (postpartum) memiliki dampak yang menguntungkan pada serum retinol bayi dan kadar retinol ASI, tetapi tidak berpengaruh terhadap pertumbuhan bayi (13). Demikian juga dengan hasil penelitian lainnya yang dilakukan di Bangladesh, Ghana, India, Indonesia, Peru, dan Thailand yang membuktikan bahwa pemberian suplementasi vitamin A pada ibu nifas tidak mempengaruhi pertumbuhan bayi (14).

Hubungan faktor sosial ekonomi keluarga dengan pertumbuhan menunjukkan bahwa pendidikan, pekerjaan, dan penghasilan orang tua tidak berpengaruh terhadap pertumbuhan bayi sejak lahir sampai dengan umur 4 bulan. Faktor sosial ekonomi kemungkinan merupakan salah satu penyebab tidak adanya pengaruh pemberian suplementasi vitamin A terhadap pertumbuhan. Hal tersebut dapat terjadi karena sebagian besar responden pada kelompok suplementasi maupun kelompok penyuluhan vitamin $A$ memiliki status sosial ekonomi (pendidikan, pekerjaan, dan penghasilan) yang hampir sama dan bayi umur 0-4 bulan umumnya juga memiliki pola makan yang sama sehingga tidak mempengaruhi pertumbuhan.

Frekuensi menyusui pada penelitian ini ditemukan sebanyak 9,96 - 10,98 kali, hasil ini lebih rendah dibandingkan hasil penelitian sebelumnya yang mendapatkan frekuensi menyusui selama 24 jam sebanyak 11 - 13 kali (12). Penelitian ini menunjukkan pula bahwa praktik pemberian ASI secara eksklusif sampai umur 4 bulan hanya sebesar $17,8 \%$ dan lebih rendah dari hasil penelitian di Sumatera Barat pada tahun 2004 yaitu 29,4\% (15). Berbagai penelitian telah menunjukkan keunggulan menyusui saja sampai 6 bulan sehingga World Health Organization (WHO) merekomendasikan agar menyusui bayi secara eksklusif sampai bayi umur 6 bulan (16). Pemberian MP-ASI atau susu formula sebelum umur 6 bulan sangat tidak dianjurkan, bayi belum mampu beradaptasi dengan makanan lain karena zat anti pada bayi belum terbentuk sehingga mudah terkena diare (17).

Pada penelitian ini ditemukan adanya pengaruh frekuensi menyusui terhadap pertumbuhan bayi sejak lahir sampai dengan umur 4 bulan. Hal ini konsisten dengan hasil penelitian terdahulu yang menunjukkan bahwa frekuensi ASI dan pemberian ASI eksklusif mempengaruhi pertumbuhan. Frekuensi menyusui menentukan jumlah asupan zat gizi dari ASI, semakin tinggi frekuensi menyusui akan semakin tinggi asupan zat gizi yang diterima oleh bayi dan sebaliknya. Dengan demikian, semakin tinggi asupan zat gizi dari ASI, pertumbuhan bayi akan semakin baik (12). Oleh karena itu, para ibu dihimbau agar meningkatkan frekuensi pemberian ASI kepada bayi untuk mencapai pertumbuhan yang lebih baik.

Rerata asupan energi bayi pada penelitian ini sudah lebih dari $80 \%$ AKG (86,4\% AKG). Pada penelitian ini, sumber pemenuhan energi bayi berasal dari ASI $(74,1 \%)$, susu formula (8,9\%), dan MP-ASI (3,5\%). Asupan energi bayi dari MP-ASI pada penelitian ini jauh lebih rendah dibandingkan dengan hasil penelitian di Aceh yaitu sebesar 68,2\% (18). Hal ini menggambarkan bahwa kesadaran untuk mengurangi pemberian MP-ASI kepada bayi sebelum umur 6 bulan sudah cukup baik. Demikian juga dengan rerata asupan protein yang sudah mencapai lebih dari $80 \%$ AKG $(95,2 \%$ AKG). Hasil penelitian ini lebih tinggi dibandingkan dengan hasil penelitian di Aceh pada tahun 2006 dengan pemenuhan protein sebesar $61,5 \%$ AKG (18).

Rerata asupan vitamin $A$ dan besi pada kedua kelompok sudah memenuhi AKG. Kecukupan vitamin $A$ terpenuhi karena disamping terpenuhi dari ASI, juga dari MP-ASI dan susu formula yang mengandung kadar vitamin A cukup tinggi. MP-ASI dan susu formula juga merupakan sumber besi bagi bayi selain ASI. Namun, asupan seng masih sangat rendah (<80\% AKG) yaitu sebesar $40,8 \%$ AKG. Rendahnya asupan seng pada sebagian besar bayi umur 0-4 bulan kemungkinan disebabkan oleh rendahnya kandungan seng pada MP-ASI dan susu formula yang dikonsumsi. Defisiensi seng menyebabkan terlambatnya pertumbuhan dan perkembangan serta dapat mengganggu respon imun (19). Selain itu, konsumsi seng yang rendah juga dapat menurunkan penyerapan besi (20).

Penelitian ini menunjukkan bahwa asupan zat gizi yang meliputi energi, protein, vitamin $A$, besi, dan seng tidak berpengaruh terhadap perubahan pertumbuhan WHZ bayi sejak lahir sampai dengan umur 4 bulan. Demikian juga dengan pemberian suplementasi vitamin A terhadap pertumbuhan $\mathrm{WHZ}$ yang tidak menunjukkan pengaruh bermakna. WHO menjelaskan bahwa telah ditemukan dalam beberapa penelitian adanya hubungan antara pertumbuhan dengan vitamin $A$, tetapi tidak semua penelitian mendukung hubungan tersebut, seperti hasil penelitian di Indonesia yang menunjukkan adanya perbaikan tambahan berat badan yang hanya terjadi pada umur 24 sampai 60 bulan (16).

Setiap bayi yang dilahirkan, rentan mengalami kekurangan vitamin A yang akan berdampak pada penurunan daya tahan tubuh sehingga meningkatkan risiko morbiditas, penyakit menular, bahkan kematian. Pemberian suplementasi vitamin A 400.000 IU pada ibu setelah melahirkan dapat meningkatkan serum retinol ASI hingga 6 - 8 bulan (21). Vitamin A lebih berperan dalam mempertahankan kekurangan vitamin A pada bayi serta melindungi risiko terhadap morbiditas dan infeksi terutama penyakit gastrointestinal. Peran vitamin A dalam penelitian 
ini bersifat protektif yang terlihat dari episode sakit diare dan ISPA pada kelompok suplementasi vitamin A yang lebih rendah secara bermakna dibandingkan kelompok yang mendapat penyuluhan. Hal ini sejalan dengan hasil penelitian di India pada tahun 2003 yang menunjukkan bahwa pemberian suplementasi vitamin A pada ibu nifas mempunyai efek terhadap penurunan insiden dan durasi sakit diare dan ISPA (22).

Efek positif vitamin $A$ berhubungan erat dengan besarnya peran vitamin A dalam diferensiasi, imunitas humoral dan selular, meningkatkan mitogenesis limfosit, meningkatkan fagositosis monosit dan makrofag, mempengaruhi sel natural killer (NK) dan sel T-helper, pembentukan substansi protektor yang non spesifik, dan pembentukan integritas jaringan epitel (23-25). Sel yang paling nyata mengalami diferensiasi adalah sel goblet yaitu kelenjar yang menyintesis dan mengeluarkan mukus yang berfungsi melindungi sel-sel epitel dari serbuan mikroorganisme. Bila terjadi infeksi, sel-sel goblet akan mengeluarkan mukus lebih banyak yang mempercepat pengeluaran mikroorganisme. Kekurangan vitamin A akan menghambat fungsi kelenjar atau membran mukosa untuk mengeluarkan cairan mukosa dengan sempurna sehingga mudah terserang infeksi. Berdasarkan penjelasan tersebut, maka efek penurunan insiden dan durasi sakit diare dan ISPA disebabkan oleh cukupnya ketersediaan vitamin A dalam tubuh untuk kebutuhan sel goblet dalam menyintesis mukus dengan sempurna sehingga dapat mengeluarkan mikroorganisme (26).

Hasil penelitian ini dengan rancangan randomized controlled trial tidak menunjukkan manfaat suplementasi vitamin A pada ibu nifas terhadap pertumbuhan bayi sejak lahir sampai dengan umur 4 bulan. Hal ini disebabkan oleh adanya proses fisiologi vitamin A dalam tubuh (intrauterin) pada masa gestasi. Sampai saat ini pemberian suplementasi vitamin A pada ibu nifas masih terjadi pebedaan pendapat (27). Selain itu, metode recall 24 jam yang digunakan untuk mencari informasi frekuensi pemberian ASI dan lamanya menyusui kurang memberikan gambaran sebenarnya karena kemampuan daya ingat setiap individu yang berbeda. Jumlah 4 hari recall 24 jam untuk mengetahui asupan vitamin $A$ dan seng masih kurang baik sebab jumlah hari recall 24 jam yang baik dengan kesalahan yang dapat ditoleransi sebesar $40 \%$ untuk vitamin A adalah 26 hari dan seng 5 hari (28).

Kelemahan dalam penelitian ini adalah tidak dilakukan pengukuran kadar vitamin A dalam ASI sebagai output suplementasi kapsul vitamin A200.000 RE dan waktu 4 bulan penelitian masih terlalu pendek untuk melihat pengaruhnya terhadap pertumbuhan. Software nUTri2008 yang digunakan untuk menganalisis asupan ASI tidak memperhitungkan suplementasi vitamin A sehingga kandungan vitamin A pada ASI ibu nifas yang mendapat suplementasi dengan ibu nifas yang mendapat penyuluhan tidak berbeda.

\section{SIMPULAN DAN SARAN}

Ibu nifas yang mendapat suplementasi vitamin $A$ dan ibu nifas yang mendapat penyuluhan vitamin A tidak berpengaruh terhadap pertumbuhan bayi umur 0-4 bulan. Namun demikian, ibu nifas yang mendapat suplementasi vitamin A mempunyai efek terhadap penurunan frekuensi sakit diare dan ISPA pada bayi dibandingkan dengan ibu nifas yang mendapat penyuluhan vitamin $A$.

Pemberian suplementasi vitamin A pada ibu nifas bermanfaat terhadap bayi umur 0 - 4 bulan. Oleh karena itu, disarankan agar seluruh ibu nifas mendapatkan suplementasi vitamin A. Perlu penelitian lanjutan mengenai pemberian suplementasi vitamin A pada ibu nifas melalui uji laboratorium kadar vitamin A dalam ASI dan pengaruhnya terhadap pertumbuhan bayi selama masa pemberian ASI secara eksklusif sampai bayi berumur 6 bulan.

\section{RUJUKAN}

1. Departemen Kesehatan RI. Pemantauan pertumbuhan balita. Jakarta: Direktorat Gizi Masyarakat; 2002.

2. Soekirman. Perlu paradigma baru untuk menanggulangi masalah gizi makro di Indonesia. [serial online] 2001 [cited 2008 Nov 26]. Available from: http://www.gizi. net

3. Latief D, Fallah TS, Sunawang. Program air susu ibu eksklusif dan makanan pendamping air susu ibu (MP-ASI). Dalam: Persatuan Ahli Gizi Indonesia, LIPI dan UNICEF. Diskusi Pakar Bidang Gizi tentang ASIMP-ASI, Antropometri dan BBLR; 2000 Jan 19-21; Jakarta.

4. Standard KL. Infections and malnutrition child mortality. Dalam: Cruickshank R, Standard KL, Russel HBL. Epidemiology and community health in warm climate countries. London and New York: Churchill Livingstone Edinburgh; 1976.

5. Sastromihardjo S. Penanggulangan diare akut pada bayi dan anak di Jakarta dan masalahnya [Thesis]. Jakarta: Universitas Indonesia; 1985.

6. Departemen Kesehatan RI. Pendidikan medik pemberantasan diare, buku ajar diare. Jakarta: Ditjen PPM dan LP Depkes RI; 1990.

7. Allen LH. Nutritional influences on linear growth: a general review. Eur J Clin Nutr 1994;48(1):S75-89.

8. West KP, Djunaedi E, Pandji A, Kusdiono, Tarwotjo I, Sommer A. Vitamin A supplementation and growth: a randomized community trial. Am J Clin Nutr 1988;48(5):1257-64.

9. Hadi H, Stoltzfus RJ, Dibley MJ, Moulton LH, West KP, Kjolhede CL, Sadjimin T. Vitamin A supplementation selectively improves the linear growth of Indonesian preschool children: result from randomized control trial. Am J Clin Nutr 2000;71(2):507-13. 
10. Helen Keller International. Program pemberian kapsul vitamin A perlu ditingkatkan agar bermanfaat untuk ibu dan anak. Buletin Kesehatan dan Gizi [serial online] 2004 [cited 2008 Dec 15];6(1):1-4. Available from: http://www.hki-ind.org/vitamina

11. Lemeshow S, Hosmer Jr DW, Klar J, Lwanga SK. Besar sampel dalam penelitian kesehatan. Pramono D. 1997 (Alih bahasa). Yogyakarta: UGM Press; 1997.

12. Widodo Y, Rianto BUD, Zulaela. Pertumbuhan bayi yang mendapat ASI eksklusif dan ASI tidak eksklusif. Sains Kesehatan 2005;18(3):427-40.

13. Vinutha $B$, Mehta MN, Shanbag $P$. Vitamin A status of pregnant women and effect of post partum vitamin $A$ supplementation. Indian Pediatr 2000;37(11):1188-93.

14. Rice, Amy L. Postpartum vitamin A supplementation: evaluating the evidence for action. [serial online] 2007 [cited 2010 Jun 12]. Available from: http://www. a2zproject.org

15. Yanwirasti. Pertumbuhan bayi yang menerima air susu ibu secara eksklusif dan non eksklusif di daerah perkotaan Sumatera Barat. Majalah Kedokteran Indonesia 2004;54(3):65-8.

16. WHO. Nutrient adequacy of exclusive breastfeeding for the term infant during the first six months of life. Geneva: WHO; 2002.

17. Soetjiningsih. ASI petunjuk untuk tenaga kesehatan, seri gizi klinik. Jakarta: Buku Kedokteran EGC; 1997.

18. Ahmad A, Boediman D, Prawirohartono E. Pola makanan pendamping air susu ibu dan status gizi bayi
0-12 bulan di Kecamatan Lhoknga Kabupaten Aceh Besar. Jurnal Gizi Klinik Indonesia 2006;3(1):6-13.

19. Whittaker P. Iron and interactions in humans. Am J Clin Nutr 1998;68(2):442S-6.

20. Kartono J, Soekatri M. Angka kecukupan mineral: besi, iodium, seng, mangan, selenium. Prosiding Widyakarya Nasional Pangan dan Gizi VIII; 2004 Mei 17-19; Jakarta, Indonesia.

21. Nalubola R, Nestle P. Effect of vitamin a nutriture on health: a review. [serial online] 1999 [cited 2010 Jun 22]. Available from: http://www.ncbi.nmhl.nih.gov/ pubmed

22. Basu S, Paladhi BS, Sengupta B. Single megadose vitamin A supplementation of Indian mothers and morbidity in breastfed young infants. Indian Postgrad Med J 2003;79(933):397-402.

23. Rahmat ES. Efek vitamin A terhadap mortalitas dan morbiditas anak. Medika 1997;5(22):362-7.

24. Lingga WJ. Kekurangan vitamin A. Medika 1989;3(15):442-6.

25. Sembiring TB. Manfaat vitamin A. Majalah Kedokteran Nusantara 2004;37(2):77-9.

26. Almatsier S. Prinsip dasar ilmu gizi. Jakarta: Gramedia; 2002.

27. Surif B, Lisal JS. Vitamin A untuk bayi berat lahir sangat rendah (BBLSR). Cermin Dunia Kedokteran 2002;144:14-6.

28. Willett W. Nutritional epidemiology. New York: Oxford University Press; 1998. 